\title{
Pemberian Sosialisasi dan Bantuan Pencegahan Covid-19 bagi Warga Malangan Kota Yogyakarta Berdasarkan Analisis Tingkat Pengetahuan
}

\author{
Rokhana Dwi Bekti ${ }^{1}$, Kris Suryowati ${ }^{2}$, Hadi Prasetyo Suseno ${ }^{3}$ \\ 1,2 Jurusan Statistika, Fakultas Sains Terapan, Institut Sains \& Teknologi AKPRIND Yogyakarta \\ ${ }^{3}$ Jurusan Teknik Lingkungan, Fakultas Sains Terapan, Institut Sains \& Teknologi AKPRIND \\ Yogyakarta \\ E-mail: ${ }^{1}$ rokhana@akprinf.ac.id, ${ }^{2}$ suryowati@akprind.ac.id, ${ }^{3}$ hp_suseno@email.ac.id
}

\begin{abstract}
Abstrak
Wabah Covid-19 yang telah melanda sangat perlu dipahami oleh penduduk di Indonesia, khususnya bagi warga di RT 37/ RW 13 Malangan, Kelurahan Giwangan, Kecamatan Umbulharjo, Kota Yogyakarta, DIY. Berdasarkan hasil analisis, dapat diketahui bahwa sebagian besar warga telah memahami gejala dan pencegahan Covid-19. Sebagian besar warga telah melakukan langkah-langkah pencegahan, namun tidak sedikit pula yang belum melakukannya. Oleh karena itu, tim melakukan kegiatan pengabdian dengan melakukan sosialisasi pengetahuan dan pecegahan, serta pemberian bantuan pencegahan. Kegiatan ini dilakukan selama seminggu di April 2020. Warga telah mendapatkan manfaat dari kegiatan ini mengingat mereka juga belum memiliki peralatan pencegahan penularan yang lengkap.
\end{abstract}

Kata kunci: Sosialisasi, Bantuan, Pencegahan, Pengetahuan, Covid-19

\begin{abstract}
The Covid-19 needs to be understood by residents in Indonesia, especially for residents in RT 37 / RW 13 Malangan, Giwangan Village, Umbulharjo District, Yogyakarta City, DIY. Based on the analysis, it can be seen that most residents have understood the symptoms and prevention of Covid-19. Most residents have taken preventative measures, but not a few who have not done so. Therefore, the team carried out community service activities by sosialization about knowledge and prevention, and providing preventative assistance. This activity was carried out for a week in April 2020. Residents have benefited from this activity because they also do not have complete transmission prevention equipment.
\end{abstract}

Keywords: socialization, assistance, prevention, knowledge, Covid-19

\section{PENDAHULUAN}

Coronavirus merupakan keluarga besar virus yang menyebabkan penyakit pada manusia dan hewan. Pada manusia biasanya menyebabkan penyakit infeksi saluran pernapasan, mulai flu biasa hingga penyakit yang serius seperti Middle East Respiratory Syndrome(MERS) dan Sindrom Pernafasan Akut Berat/ Severe Acute Respiratory Syndrome (SARS). Coronavirus jenis baru yang ditemukan pada manusia sejak kejadian luar biasa muncul di Wuhan Cina, pada Desember 2019, kemudian diberi nama Severe Acute Respiratory Syndrome Coronavirus 2 (SARS-COV2), dan menyebabkan penyakit Coronavirus Disease-2019 (COVID-19).Seperti penyakit pernapasan lainnya, COVID-19 dapat menyebabkan gejala ringan termasuk pilek, sakit tenggorokan, batuk, dan demam.

Pada saat ini masih dilakukan penelitian tentang penyebab munculnya wabah pandemi Covid-19, obat, hingga faktor-faktor yang mempengaruhinya. Pemerintah telah 
mensosialisasikan langkah-langkah pencegahan hingga Keputusan Presiden (KP). Pada 13 Maret 2020 telah dibentuk Gugus Tugas Percepatan Penanganan COVID-19 di Indonesia. Gugus tugas ini berada dalam lingkup Badan Nasional Penanggulangan Bencana, dengan melibatkan kementerian, lembaga, dan unit pemerintahan lain seperti Kementerian Kesehatan, Kepolisian Negara Republik Indonesia, Tentara Nasional Indonesia, dan pemerintah di daerah.

Kegiatan pengabdian kepada masyarakat akan memberi peran penting untuk mendukung program pemerintah dalam menangani Covid-19. Beberapa peneliti dan pengabdi yang telah melakukannya adalah [1] yang telah melakukan peningkatan pengetahuan masyarakat Desa Jelantik dalam menghadapi pandemi melalui penyuluhan kesehatan. [2] telah melakukan analisis tentang peran pemuda tani dalam pencegahan penyebaran covid-19 di tingkat petani di Kabupaten Magelang. Berbagai program pengabdian menjadi penting, karena wabah ini telah memberikan dampak besar pada ekonomi. Penelitian [3] dan [4] mengkaji bahwa penyebaran penyakin ini memberikan dampak pada krisis ekonomi global.

Berdasarkan sumber dari Pemerintah Daerah DIY, jumlah pasien positif Covid-19 di Propinsi DIY pada 21 Maret 2020 adalah 4 pasien, 1 PDP, dan 420 ODP. Angka ini terus meningkat pada 21 Mei 2020 menjadi 215 positif, 1.160 PDP, dan 6.213 ODP. Dari sejumlah 215 terdapat 102 di rawat, 105 telah sembuh, dan 8 meninggal. Sementara itu menurut data pada 29 April 2020, di Wilayah Kecamatan Umbulharjo, Kota Yogyakarta terdapat jumlah pasien positif 2 orang dan PDP 16 orang [5].

Perilaku warga dalam menanggapi dan mencegah penyebaran virus belum sepenuhnya sesuai dengan program-program pemerintah dalam memutus mata rantai virus ini. Penelitian [6] telah menganalisis bahwa tingkat pengetahuan masyarakat berpengaruh terhadap kepatuhan penggunaan masker. Oleh karena itu, agenda sosialisai dan pendekatan kepada warga menjadi sangat penting dilakukan. Sosialisasi dapat dilakukan diberbagai media. [7] menyatakan bahwa sosialisasi di media massa menunjukkan strong effect bahkan mampu membentuk persepsi masyarakat tentang pencegahan penularan covid-19 kepada individu.

Warga di RT 37/ RW 13 Malangan, Kelurahan Giwangan, Kecamatan Umbulharjo, Kota Yogyakarta, DIY memiliki luas wilayah 1,26 km2, dengan jumlah penduduk 259 jiwa. Wilayah ini berada di wilayah padat penduduk dan rentan terjadi penularan. Melihat kondisi ini maka sangat penting sekali bagi warga untuk menjaga diri dan keluarga agar tidak terjangkit penyakit ini. Salah satu upaya yang dapat dilakukan adalah dengan melakukan sosialisasi tentang gejala dan pencegahan Covid-19 kepada seluruh lapisan masyarakat. Pengetahuan yang lebih akurat dan dapat dipercaya akan dapat membantu masyarakat untuk mudah melaksanakan himbuan dan arahan pemerintah guna menekan penyebaran Covid-19. Oleh karena itu tim melakukan sosialisasi untuk meningkatkan pengetahuan warga di RT 37 RW 13 Malangan agar dapat menghadapi dan melewati pandemi Covid-19. Selain itu, tim juga memberikan bantuan pencegahan Covid-19, mengingat penyakit ini adalah hal baru bagi warga dan terbatasnya alatalat pencegahan.

\section{METODE PELAKSANAAN PENGABDIAN}

Pelaksanaan kegiatan meliputi persiapan, pelaksanaan, pelaporan, hingga tindak lanjutnya. Penjelasan masing-masing adalah sebagai berikut:

a. Persiapan dilakukan dengan melakukan koordinasi bersama Ketua RT terkait program pengabdian yang akan dilaksanakan. Koordinasi dilakukan melalui komunikasi online.

b. Karena wabah penyakit Covid-19 ini merupakan hal baru bagi warga, maka tim terlebih dahulu melakukan survei dan analisis situasi yaitu dengan melakukan observasi maupun survei kepada warga RT 37 RW 13 Malangan. tentang pengetahuannya terhadap Covid-19 dan pencegahannya. Penyebaran kuisioner adalah secara online pada April 2020. Dari data yang terkumpul, dilakukan analisis data untuk mengetahui tingkat pemahaman warga dan kegiatan pencegahan yang telah mereka lakukan. Metode analisis adalah metode statistik, yaitu analisis deskriptif dan uji Chi Square. 
c. Pelaksanaan sosialisasi pengetahuan Covid-19 dan pencegahanya. Kegiatan ini dilakukan secara online dan pembagian poster kepada warga.

d. Pemberian bantuan pencegahan Covid-19.

\section{HASIL DAN PEMBAHASAN}

Berdasarkan hasil survei kepada warga RT 37 RW 13 Malangan, sebagian besar dari mereka telah memahami Covid-19 dan pencegahanya. Sejumlah 37.8 persen menyatakan paham dan $35.14 \%$ menyatakan sangat paham tentang gejala Covid-19. Namun demikian masih ada $24.32 \%$ yang menyatakan kurang paham dan $2.7 \%$ menyatakan tidak paham. Berkaitan dengan cara pencegahannya sejumlah 40.54 persen menyatakan sangat paham, 40.54 persen menyatakan paham, dan 18.92 persen menyatakan kurang paham. Berdasarkan data ini dapat diketahui bahwa warga telah memahami cara-cara pencegahan covid-19 walaupun belum memahami sepenuhnya tentang gejala-gejalanya. Fakta ini menunjukkan bahwa sosialisasi tentang pencegahan yang diberikan pemerintah dan pihak-pihak terkait melalui berbagai media telah membuahkan hasil, walaupun masih ada beberapa yang belum memahami.

Tim melakukan analisis tingkat pemahaman warga RT 37 RW 13 Malangan di setiap jenjang usia, tingkat pendidikan, dan jenis kelamin. Selanjutnya tim pengabdian melakukan sosialisasi tentang Covid-19 dan pemberian bantuan pencegahan kepada warga.

\subsection{Analisis Pemahaman tentang Covid-19 berdasarkan Usia, Tingkat Pendidikan, dan Jenis Kelamin}

Gambar 3, Gambar 4, dan Gambar 5 menunjukkan tingkat pemahaman warga berdasarkan usia, pendidikan, dan jenis kelamin. Dapat diketahui bahwa beberapa warga yang tidak atau belum memahami tentang gejala dan pencegahan covid-19 berada di usia 30 tahun ke atas, namun persentase terbanyak ada di rentang usia 30-39 tahun. Sedangkan warga yang berusia 20-29 tahun memiliki pemahaman lebih tinggi. Berdasarkan pendidikan, semakin tinggi jenjang pendidikan belum menjamin mereka akan lebih memahami. Masih ada warga dengan jenjang pendidikan SLTA/sederajat dan Perguruan Tinggi yang kurang paham dengan covid-19 dan pencegahannya. Sementara itu, tingkat pemahaman anatara warga laki-laki dan perempuan juga berbeda. Warga perempuan memiliki tingkat pemahaman yang lebih tinggi dibandingkan laki-laki. Hal ini ditunjukkan oleh persentase warga perempuan yang menyatakan paham dan sangat paham terhadap gejala dan pencegahan adalah sebesar 79\% dan $95 \%$.

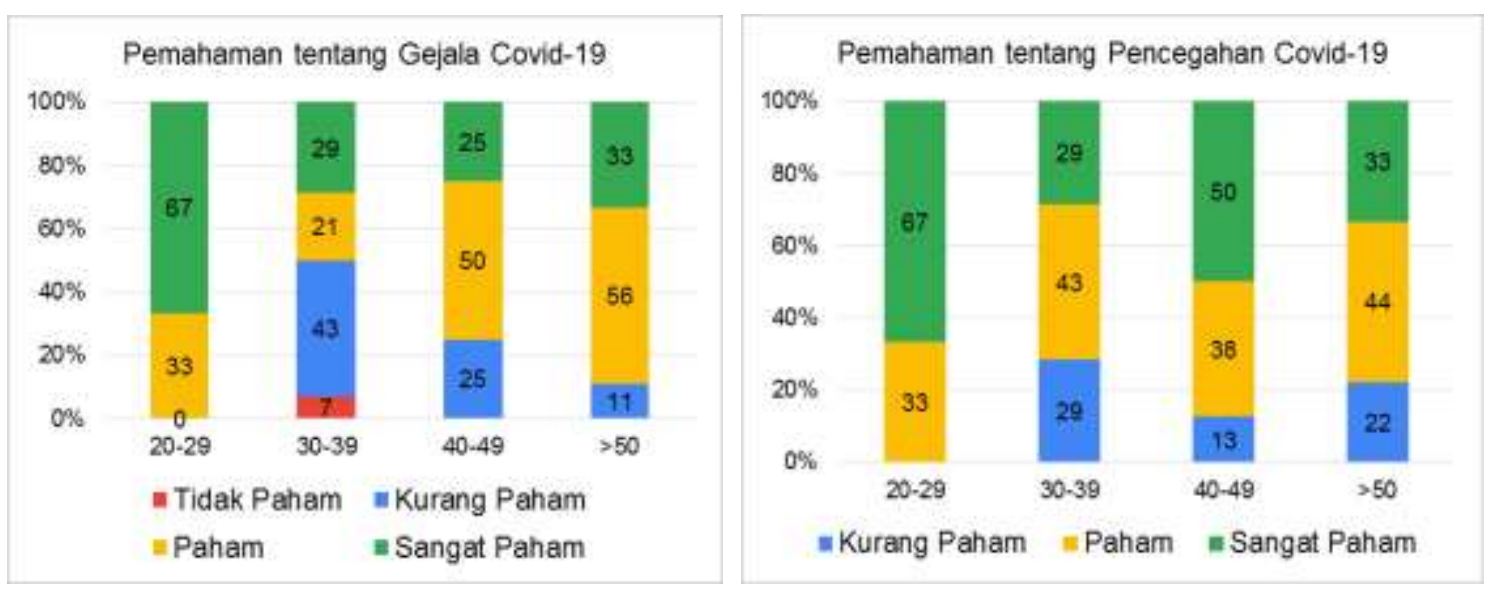

Gambar 3. Pemahaman Warga tentang Gejala dan Pencegahan Covid-19 Berdasarkan Usia 


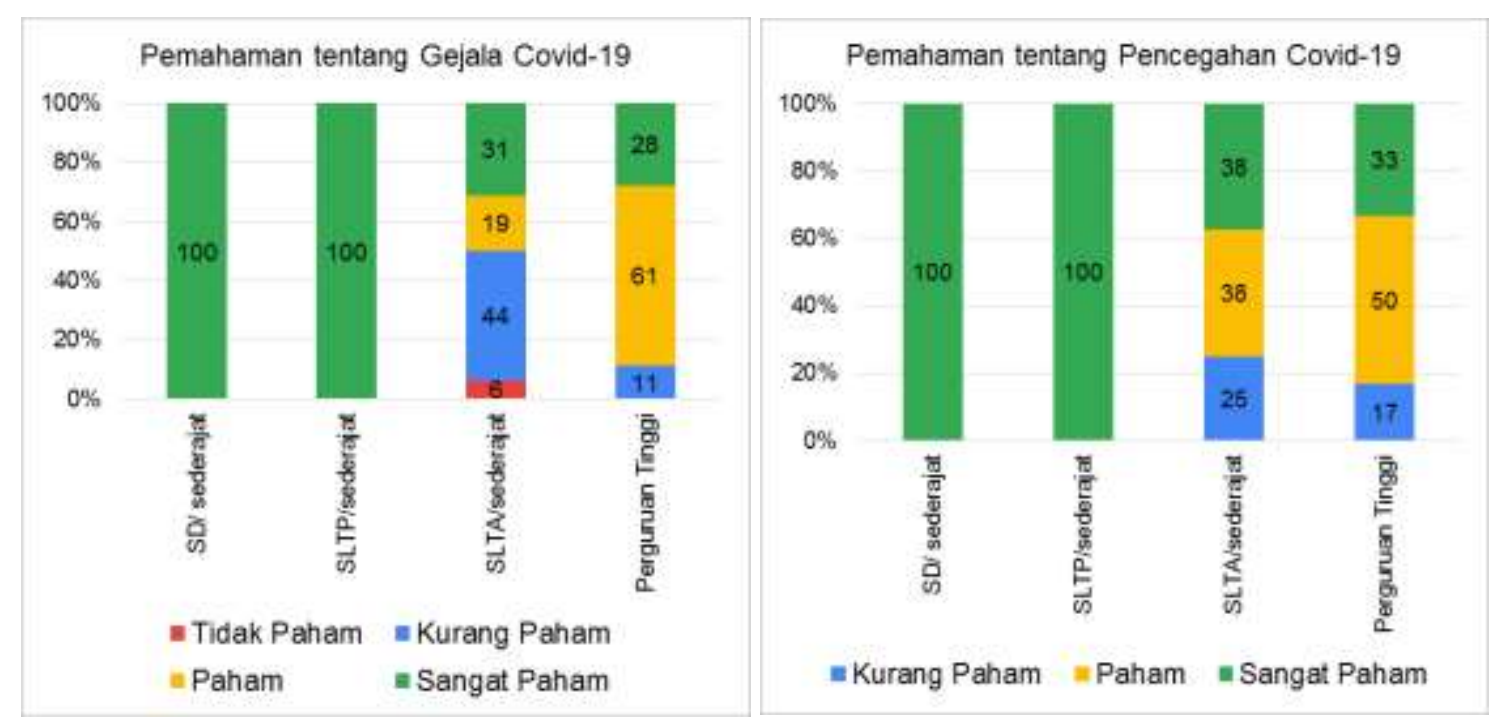

Gambar 4. Pemahaman Warga tentang Gejala dan Pencegahan Covid-19 Berdasarkan Pendidikan

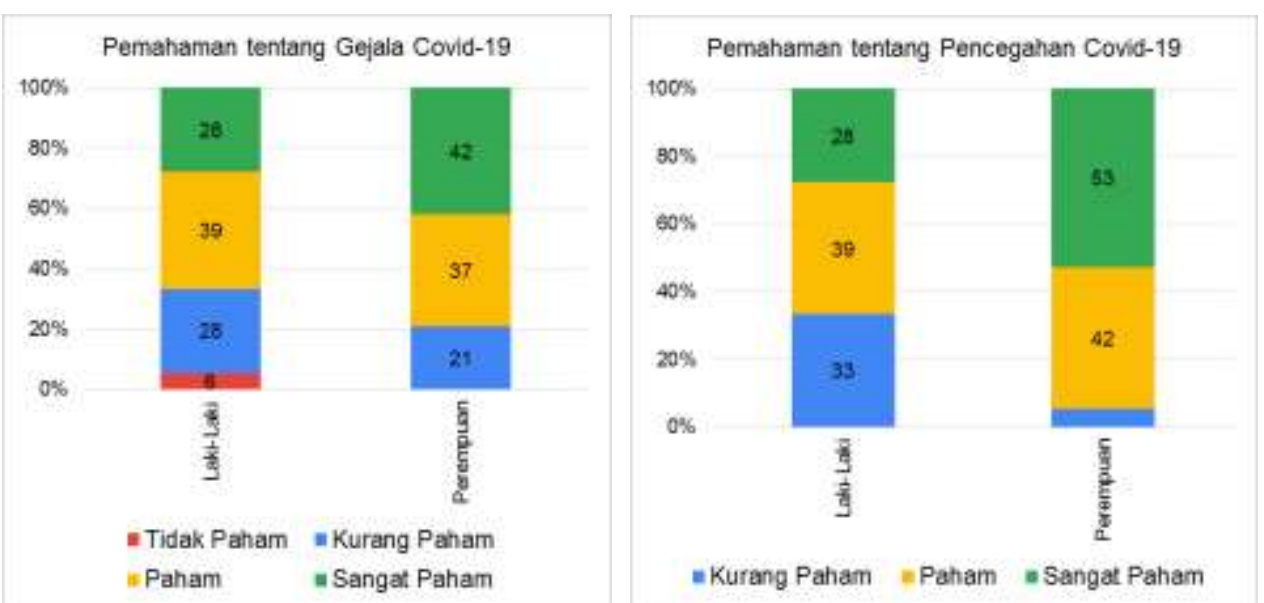

Gambar 5. Pemahaman Warga tentang Gejala dan Pencegahan Covid-19 Berdasarkan Jenis Kelamin

Secara statistik, pengaruh usia, pendidikan, dan jenis kelamin terhadap pengetahuan tentang gejala dan pecegahan Covid-19 dapat diuji yaitu menggunakan metode uji Chi-Square. Hipotesis yang digunakan adalah

Ho : usia, pendidikan, atau jenis kelamin tidak berpengaruh terhadap pengetahuan tentang gejala/pecegahan Covid-19

$\mathrm{H}_{1}$ : usia, pendidikan, atau jenis kelamin berpengaruh terhadap pengetahuan tentang gejala/pecegahan Covid-19

Hasil pengujian disajikan pada Tabel. Usia, pendidikan, atau jenis kelamin terbukti berpengaruh terhadap pengetahuan tentang gejala/pecegahan Covid-19 apabila nilai $\mathrm{P}$ value kurang dari $\alpha$. Dengan $\alpha=10 \%$ maka dapat disimpulkan bahwa tingkat pendidikan signifikan berpengaruh terhadap pengetahuan tentang gejala Covid-19 dan jenis kelamin signifikan berpengaruh terhadap pengetahuan tentang pencegahan Covid-19. 
Tabel 1. Hasil Uji Chi-Square

\begin{tabular}{|l|l|l|}
\hline \multicolumn{1}{|c|}{ Karakteristik } & \multicolumn{1}{|c|}{ Gejala } & \multicolumn{1}{c|}{ Pencegahan } \\
\hline Usia & $X^{2}=9.926$ & $X^{2}=3.995$ \\
& P value $=0.356$ & P value $=0.677$ \\
\hline Tingkat pendidikan & $X^{2}=15.007$ & $X^{2}=5.462$ \\
& P value $=0.091$ & P value $=0.486$ \\
\hline Jenis Kelamin & $X^{2}=1.778$ & $X^{2}=5.282$ \\
& P value $=0.620$ & P value $=0.071$ \\
\hline
\end{tabular}

Lebih detail tentang pemahaman pencegahan Covid-19 maka disajikan Gambar 6 berikut mengenai perilaku pencegahan Covid-19 yang telah dilakukan warga setempat sejak seminggu terakhir ketika survei dilakukan. Secara umum, mereka telah melakukan (sering dan selalu) memakai masker, menggunakan handsanitizer, mencuci tangan, menghindari menyentuh wajah, menghindari jabat tangan, menghindari pertemuan atau antrian panjang, menyentuh benda di tempat umum, menghindari transportasi umum, menjaga jarak, dan memberi tahu orang jika menunjukkan gejala penyakit. Namun demikian, masih ada warga yang menyatakan tidak pernah menghindari jabat tangan, menghindari menyentuh benda di tempat umum, menjaga jarak, dan memberi tahu orang jika menunjukkan gejala penyakit. Tentang memakai sarung tangan ketika keluar rumah, hanya sedikit yang sering dan selalu menggunakan.

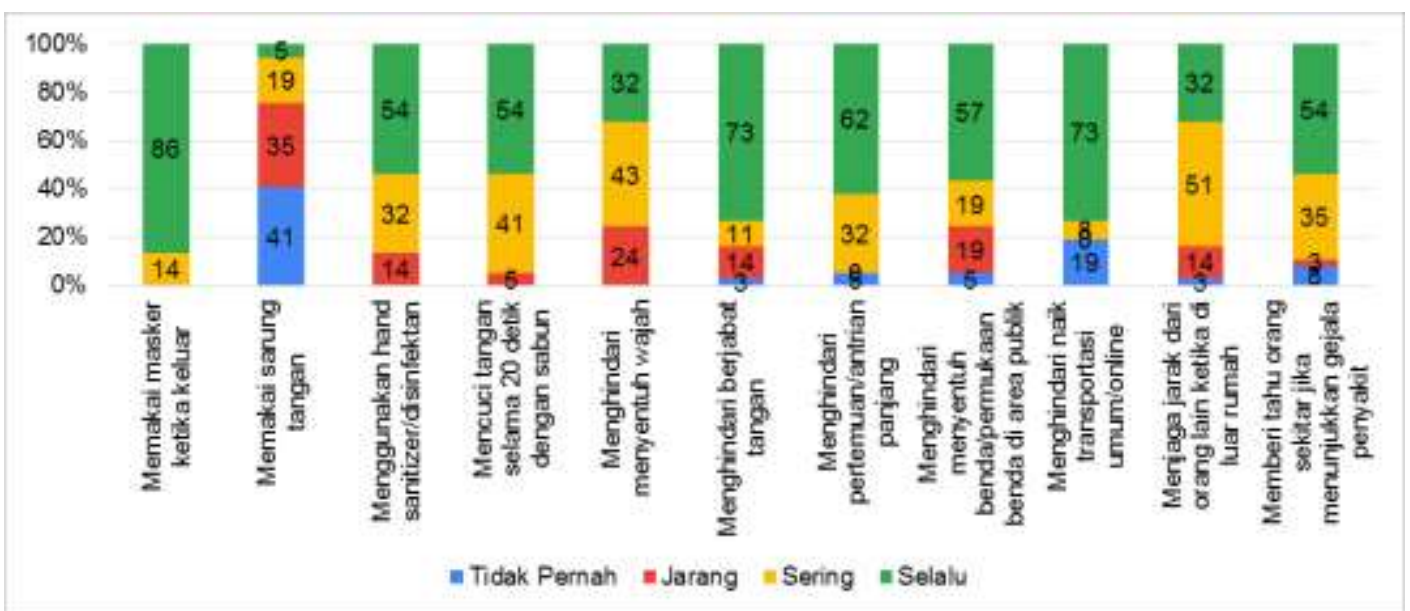

Gambar 6. Perilaku dalam Pencegahan Covid-19.

\subsection{Sosialisasi dan Pemberian Bantuan Pencegahan Covid-19}

Tim pengabdi telah mendapatkan hasil survei bahwa warga RT 37 RW 13 Malangan masih memerlukan sosialisasi dan bantuan pencegahan Covid-19. Oleh karena itu tim pengabdian mengadakan kegiatan tersebut pada 18-26 April 2020 di Balai RT (lihat Gambar 7). Kegiatan dilakukan dengan tetap mematuhi aturan pencegahan Covid-19, yaitu hanya dihadiri ketua RT dan perwakilan warga. Bentuk sosialisasi adalah dengan metode ceramah singkat dan membagikan poster tentang definisi, gejala, dan cara pencegahanya. Poster dibuat sedemikian rupa sehingga menarik bagi pembaca dan mudah dipahami. Materi bersumber dari Satgas Covid-19 RI dan Badan Nasional Penanggulangan Bencana (BNPB).

Materi sosialisasi menekankan bahwa warga harus mengetahui ciri-ciri gejala clinis Covid-19 dan mematuhi himbauan pemerintah tentang pencegahanya. Gejala klinis tersebut diantaranya flu dan batuk, demam tinggi, sakit tenggorokan, dan sesak nafas atau nyeri pada dada. Upaya-upaya pencegahan juga harus dilakukan dengan disiplin, diantaranya:

1. Menjaga jarak paling sedikit 1 meter dengan orang lain, serta menghindari berkumpul dengan banyak orang

2. Menghindari menyentuh wajah, seperti mulut, hidung, dan mata 
3. Mencuci tangan menggunakan sabun dan air mengalir minimal 20 detik sesering mungkin. Gunakan cairan pembersih tangan (minimal 60\% alkohol) bila sabun dan air mengalir tidak tersedia

4. Menutup mulut dan hidung dengan siku atau gunakan masker saat batuk dan bersin, atau menggunakan tisu yang langsung dibuang ke tempat sampah tertutup setelah digunakan

5. Produktif dirumah, sekolah dirumah, bekerja dirumah, ibadah dirumah sementara.

Upaya-upaya lain yang perlu dilakukan adalah membiasakan hidup sehat dan bersih, diantaranya makan makanan bergizi untuk menjaga imunitas tubuh, makan dan minum teratur dan cukup, olahraga, menjaga lingkungan yang bersih, dan lain sebagainya. Tubuh dan lingkungan yang sehat akan membantu terhindar dari berbagai penyakit, salah satunya Covid19.

Ketua RT 37 RW 13 Malangan menyampaikan bahwa mereka mereka masih kekurangan peralatan pencegahan Covid-19, oleh karena itu tim juga memberikan bantuan. Bantuan-bantuan tersebut berupa handsanitizer, makser, peralatan cuci tangan, dan APD. Bantuan tersebut dibagikan ke rumah-rumah warga dan petugas penanganan Covid-19.

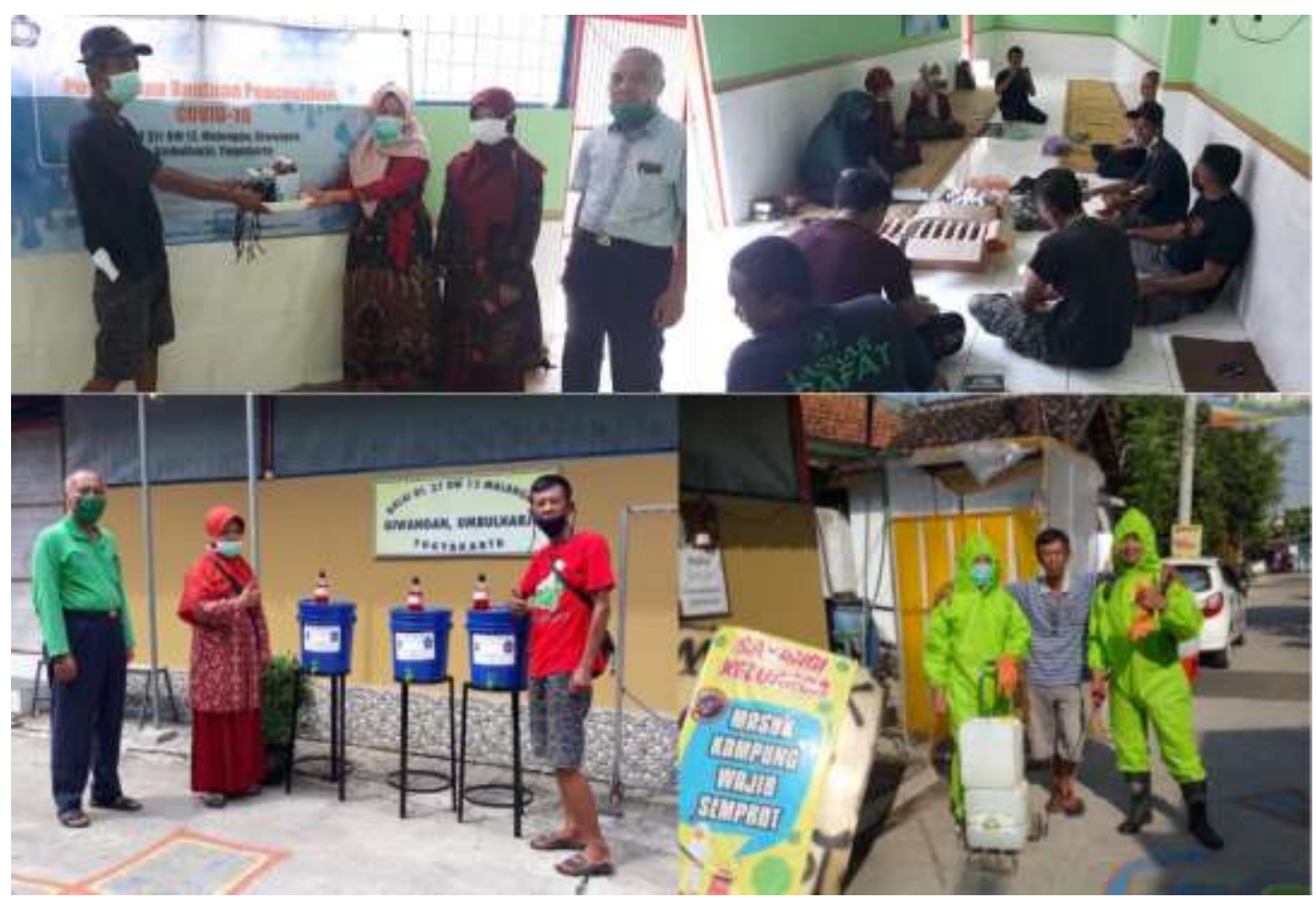

Gambar 7. Sosialisasi dan Pemberian Bantuan Pencegahan Covid-19

Kegiatan yang telah dilakukan tim telah memberikan banyak manfaat ke warga. Diantaranya perlengkapan untuk pencegahan Covid-19 menjadi lengkap, sehingga dapat mencegah penularan Covid-19 di lingkungan warga. Warga di sini juga memiliki peran dalam memelihara dan menggunakan perlengkapan dengan sebaik-baiknya.

\section{KESIMPULAN DAN SARAN}

Berdasarkan rangkaian kegiatan pengabdian yang telah dilakukan, maka kesimpulan dari kegiatan ini adalah pengetahuan warga RT 37 RW 13 Malangan tentang Covid-19 dan pencegahanya masih perlu ditingkatkan. Sebagian besar warga telah melakukan himbauan- 
himbauan dari pemerintah dalam pencegahannya, namun edukasi-edukasi masih perlu terus dilakukan. Kegiatan sosialisasi yang telah dilakukan tim telah menambah pengetahuan warga tentang penyakit ini, sehingga mereka dapat lebih aktif dalam melakukan pencegahan. Bantuan perlengkapan pencegahan yang diberikan juga dapat menjadi bekal supaya terhindar dari Covid19.

Berbagai upaya lain juga perlu terus dilakukan untuk menjaga kestabilan sosial ekonomi mengingat wabah ini memberikan dampak serius bagi ekonomi warga. Diantaranya bagaimana usaha/industri lokal tetap bisa bertahan, warga yang kehilangan pekerjaan tetap dapat memenuhi kebutuhan sehari-hari, dan lain sebagainya.

\section{UCAPAN TERIMA KASIH}

Tim mengucapkan terimakasih kepada laboratorium teknik lingkungan dan laboratorium statisika di IST AKPRIND Yogyakarta yang telah memberikan fasilitas pendukung dan Kementerian Riset dan Teknologi / Badan Riset dan Inovasi Nasional Republik Indonesia yang telah memberikan dana hibah Program Kemitraan Masyarakat (PKM)

\section{DAFTAR PUSTAKA}

[1] Sulaeman, S., \& Supriadi, S. 2020. Peningkatan Pengetahuan Masyarakat Desa Jelantik Dalam Menghadapi Pandemi Corona Virus Diseases-19 (Covid-19). Jurnal Pengabdian UNDIKMA, No 1, vol 1, 12-17.

[2] Hartati, P., \& Susanto, S. 2020. PERAN PEMUDA TANI DALAM PENCEGAHAN PENYEBARAN COVID-19 DI TINGKAT PETANI (KASUS DI KABUPATEN MAGELANG). BASKARA: Journal of Business \& Entrepreneurship, No 2, Vol 2, 107 112.

[3] Burhanudin, CI. Dan Abdi, M. N. 2020. KRISIS EKONOMI GLOBAL DARI DAMPAK PENYEBARAN VIRUS CORONA (COVID-19). AkMen JURNAL ILMIAH, No 1, Vol 17, 711-719.

[4] Aminul, M. 2020. PERILAKU PRODUKSI DI TENGAH KRISIS GLOBAL AKIBAT PANDEMI COVID-19 DAN MEMANFAATKAN MEDIA ONLINE FACEBOOK SEBAGAI ALTERNATIF PASAR. EMISI (Jurnal Ekonomi, Manajemen dan Akuntansi).

[5] Pemda DIY. 2020. Data Terkait Covid-19 di DI Yogyakarta. Diakses di https://corona.jogjaprov.go.id/data-statistik

[6] Sari, D. P., \& Sholihah'Atiqoh, N. 2020. HUBUNGAN ANTARA PENGETAHUAN MASYARAKAT DENGAN KEPATUHAN PENGGUNAAN MASKER SEBAGAI UPAYA PENCEGAHAN PENYAKIT COVID-19 DI NGRONGGAH. INFOKES Journal, No 1, Vol 10, 52-55.

[7] Triyaningsih, H. 2020. Efek Pemberitaan Media Massa Terhadap Persepsi Masyarakat Tentang Virus Corona (Studi Kasus; Masyarakat di Pamekasan). Meyarsa: Jurnal Ilmu Komunikasi dan Dakwah, No 1, Vol 1, 1-15 